\title{
Normalizált indexek alkalmazhatósága automa- tikus területi klasszifikációhoz Magyarországon Baranya megye példáján
}

\author{
Farkas Gábor
}

doktorandusz, Pécsi Tudományegyetem, Földtudományok Doktori Iskola, E-mail: randal73@gamma.ttk.pte.hu

\begin{abstract}
Absztrakt
Az elsö multispektrális adatok megjelenése óta foglalkoztatja a kutatókat az ilyen adatok kiértékelése különbözö módszerekkel. Igazán elterjedt módszer az automatikus, vagy felügyelt klasszifikáció, mely során különbözö spektrális tartományokban készült képekböl dimenziócsökkentö eljárásokkal osztályozott állományok készülnek. Egyik fontos célja a klasszifikációs eljárásoknak a felszínboritás térképezése, monitorozása. A tanulmány erre a célra mutat be részletesen egy teljesen automatizálható, költséghatékony megoldást. Bár a kutatáshoz használt, népszerübbek közé tartozó négy normalizált index (NDVI, NDWI, NDBaI, NDBI) alkalmazhatósága Magyarország területén megkérdőjelezhetö, a spektrálisan leginkább eltérö felszínboritási formákat (vízborítás, sürü növényzet, kopár terület) az ezekkel készült klasszifikáció jól kirajzolja.
\end{abstract}

Kulcsszavak Baranya, képfeldolgozás, klasszifikáció, klaszteranalizis, maximum likelihood classification, normalizált indexek

DOI: 10.17799/2015.1.13

\section{Bevezetés}

A távérzékelés tudományának manapság csupán apró szeglete a multispektrális szenzoroktól származó képek GIS rendszerek segítségével történő elemzése. Ezek a képek túlnyomó részben müholdakról származnak. Mika et al. (2011) szerint már az 1950-es évek óta foglalkoztatják a kutatókat a képi adatok feldolgozásában rejlő lehetőségek, míg az első multispektrális szenzor prototípusa 1962-ben született meg (Lein 2003). Az elmúlt 50 év alatt jelentős fejlődésen mentek keresztül mind a szenzorok, mind az elemzési eljárások. Mára fejlett algoritmusok, mint az MLC (maximum likelihood classification), vagy a MAP (maximum a posteriori) állnak a kutatók rendelkezésére, hogy ezeket a müholdképeket akár automatikusan, akár felügyelten kiértékeljék. Bár a távérzékelő müholdak egy részének - mint például a $4 \mathrm{~m}$-es felbontású IKONOS (Garrison et al. 2008) - adatai kereskedelmi forgalomban vannak, ingyenes minőségi adatokhoz sem bonyolult hozzájutni. Az Egyesült Államok adatpolitikájának köszönhetően például ingyenesen hozzáférhetünk az egyik legnagyobb müholdkép adatbázishoz, a Landsat archívumhoz (Wulder et al. 2012).

Az USGS (2015) közlése alapján az első Landsat műholdat, a Landsat 1-et 1972-ben állították pályára. Ez a mühold mindössze négy spektrális csatornán rögzített.
Jelenleg a Landsat 7 ETM+ (Enhanced Thematic Mapper + ), és a Landsat 8 OLI (Operational Land Manager) szolgáltat folyamatosan frissülő képeket nyolc, illetve kilenc spektrális tartományban. Az 1972 óta felvett adatok napjainkban ingyenesen elérhetőek, általuk a földfelszínen végbemenő változások széles időintervallumon elemezhetőek. Ezeknek az elemzéseknek egyik célja a felszínborítás vizsgálata. Az ilyen típusú kutatások tárgya lehet egy egyszerü terület-, vagy földhasználati térkép elöállítása, vagy akár egy specifikus faj terjedésének, térbeli eloszlásának vizsgálata.

A nyers müholdképek adattárolási megfontolásokból kvantált formában tartalmazzák az érzékelt információt. Minden müholdkép és szenzor esetében visszaszámolhatóak a rögzített értékek. A NASA (2011) által kiadott Landsat 7 kézikönyv szerint a kvantált értékek radiancia, és reflektancia értékekké számolhatóak vissza, melyek a szenzort érő sugárzás mennyiségét, valamint a visszavert energia arányát reprezentálják. Amíg általában a reflektancia értékek szolgálnak egy távérzékelési vizsgálat alapjául, más derivatív termékek is alkalmazhatóak hasonló célra. Tipikusan ilyen adatok a normalizált indexek. Ahogy Eredics (2007) is összefoglalja, ezek dimenzió nélküli méröszámok. Az NDVI a növényzet klorofill tartalmával áll összefüggésben. Gyakori mérőszám még a Gao (1996) által bevezetett NDWI (normalizált ned- 
vességindex), mely a növényzet nedvességtartalmával korrelál. Kevésbé ismert, ámbár igen hasznos normalizált index az NDBI, azaz a normalizált beépítettség index (Chen et al. 2006), valamint az NDBaI, vagyis a normalizált kopárság index (Zhao et al. 2005). Amíg az NDBI a beépített területekre érzékeny, az NDBaI a vegetációmentes, kopár területeket emeli ki.

Mivel ezek az indexek azon eltérő karakterisztikáit emelik ki a felszínnek, melyek alkalmasak lehetnek egy általános felszínborítottságot ábrázoló állomány elkészítéséhez akár teljesen automatikus eszközökkel is, ez a tanulmány hipotézise. A hipotézist erősíti, hogy Chen et al. (2006) már sikeresen alkalmazott egy hasonló módszert Kína területén belül, ahol az indexek jó elszeparálhatóságából adódóan határértékek segítségével sikerült hét felszínborítási típust (kopár terület, víz, halastó, félig kopár terület, beépített terület, erdő, termőföld) nagy pontossággal leválogatnia.

A tanulmány célja egy teljesen automatizálható módszer pontosságának a vizsgálata, mely spektrális indexeket használ az automatikus osztályozáshoz. Így, amenynyiben bizonyítást nyer a módszer alkalmassága, azt költséghatékony módon lehet alkalmazni, mivel az emberi munkaerő költsége csak egyszeri.

\section{Módszerek}

\subsection{Kiinduló adatok}

Elsőként pontos referenciaadatokra volt szükség, mely a pontosságvizsgálatot megalapozza. Kritériuma volt a referenciaként szolgáló állománynak, hogy ingyenes legyen, mivel a tanulmánynak nem volt költségvetése. Így a választás a FÖMI által kiadott CLC50 (Corine Land Cover) állományra esett, amely Magyarország 2000-es felszínhasznosítási viszonyait ábrázolja nagy méretarányban (1:50 000). Ahogy Büttner et al. (2009) öszszefoglalja az adatokhoz kiadott jelentésben, a CLC50 felbontása a kötelező CLC100-as adatoknak vonalas elemekre a duplája, míg a területi felbontása több mint ötszöröse. A helyzeti pontosságot $20 \mathrm{~m}$ alattinak adja meg, a tematikus megbízhatóságot pedig $90 \%$ felettinek. Ezen technikai paraméterek alapján a CLC50 vektoros állomány megbízható referenciaként szolgálhat a kutatáshoz.

Az elemzés második kiinduló állománya az osztályozandó müholdkép. Erre a célra az ingyenesen elérhető Landsat 7 állományra esett a választás. A CLC50 állomány a 2000-es állapotot örökíti meg, továbbá Chen et al. (2006) is ETM+ szenzorból származó adatokkal végzett sikeres osztályozást, így megfelelőnek tüntek a 2000-es Landsat 7 felvételek. Megfigyelhető a CLC50 állományban Baranya megyén belül a kopár (növényzettel nem borított) területek majdnem teljes hiánya, viszont ez egy meghatározó kategória az elemzésben. Ennek a problémának orvosolására a tanulmány októberi felvételekre támaszkodik (2000. október 14.), amikor már az utolsó őszi aratások is javarészt megtörténtek. Így a CLC50 helyes klasszifikációjával a referencia is helyes lesz, valamint az osztályozó algoritmus is elég mintához jut a helyes klasszifikáció elvégzéséhez. Természetesen azokon a területeken, ahol a betakarítás még nem történt meg az előbb említett időpontban, a pontossági elemzés hibás lesz, azonban a mintaterület nagysága révén ez a hibaszázalék elhanyagolható.

\subsection{A CLC50 állomány újraosztályozása}

Kezdő lépésként a referenciaadatot, azaz a CLC50 vektoros állományt az októberi viszonyoknak megfelelően kellett újraosztályozni. Fontos megemlíteni, hogy a Corine Land Cover projekt célja egy konzisztens európai felszínborítási téradatbázis létrehozása melyben területhasználati elemek is fontos szerepet kapnak (Feranec et al. 2007), míg a kutatás célja csak a felszínborítás automatikus osztályozása. A két termék eltér, méghozzá idő dimenzióban. A területhasználat független a szezonális változásoktól, míg a felszínborítás függ a felvétel időpontjától. A két termék közös nevezőre hozásának kézenfekvő módszere a területhasználati állomány újraosztályozása az elméleti szezonális viszonyoknak megfelelően.

A FÖMI (2009) által kiadott CLC50 nómenklatúrából nem csupán az osztályelemek olvashatók ki, hanem azok rövid leírása és az osztályok kritériumrendszere is. Az újraosztályozást így az egyes osztályok és alosztályok értelmezésével el lehet végezni (1. táblázat). Minden csoport és alcsoport a legmeghatározóbb területhasználati forma alapján került besorolásra. Azok a mezőgazdasági területek szakadtak ketté, ahol a szántóföldek a kopár területekhez lettek sorolva, míg a szőlők, és a természetes növényzettel borított területek a gyér növényzethez. Az erdők és a vizenyős területek nem szezonális felhasználási formák, így újraosztályozásuk egyértelmủ volt, míg a vízzel borított területekhez a természetes vizek mellett besorolásra kerültek a folyékony hulladéktároló telepek.

\begin{tabular}{ccc}
\hline Osztály & Kat. & CLC50 kód \\
\hline $\begin{array}{c}\text { Beépített } \\
\text { terület }\end{array}$ & 1 & $1100-1300,1420-2000,12110-13000$, \\
& & 1331,2113 \\
Gyér & 2 & $1410-1420,2200-2430,2432,2433,2435$, \\
növényzet & & $3240-3300,22110-25000$ \\
Erdő & 3 & $3100-3240$ \\
Kopár & 4 & $1310-1321,2100-2200,3300-4000$, \\
terület & & 2431 \\
Vizenyős & 5 & $4000-5000$ \\
terület & & $5000-10000,50000-60000,1322$ \\
Víz & 6 &
\end{tabular}

1. táblázat. CLC50 októberi újraosztályozása

A hat vizsgálandó osztály kialakítása, és a vektoros állomány újraosztályozása után az utolsó lépés raszterré alakítani a poligonokat. Mivel a Landsat 7 felvételek tér- 
beli felbontása $30 \mathrm{~m}$, az átalakított referencia állomány (1. ábra) felbontása is erre az értékre esett.

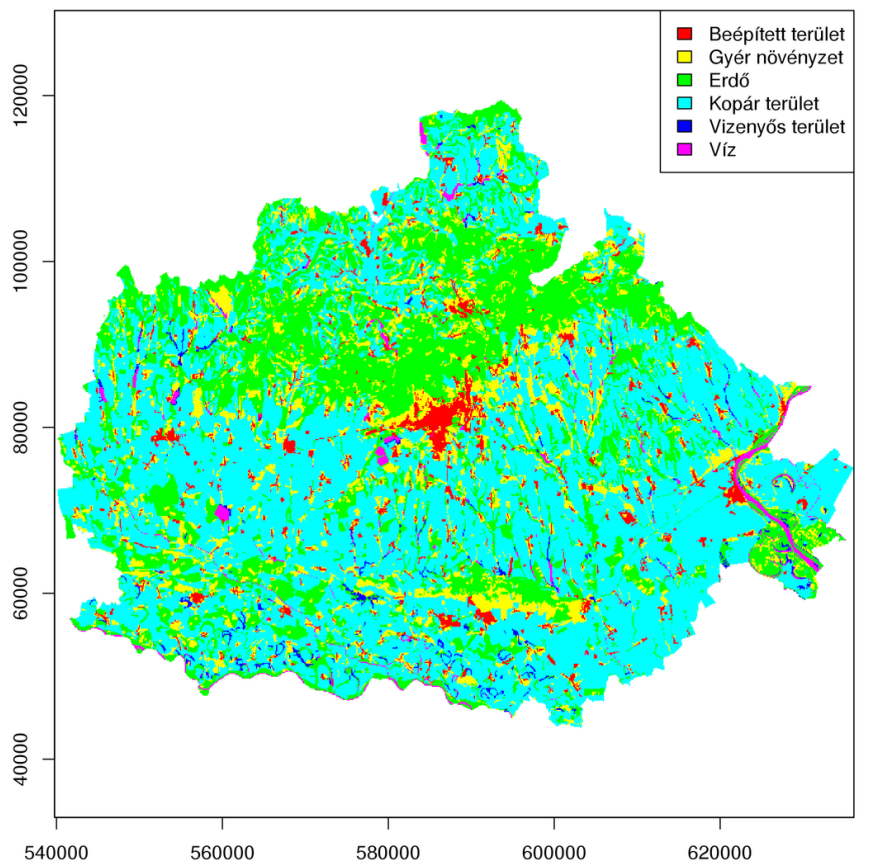

\section{1. ábra. CLC50 állomány újraosztályozva, raszterré konvertálva}

\subsection{A spektrális indexek létrehozása}

Az indexek előállításához először a Landsat müholdképek átalakítására volt szükség. Az elemzést megkönnyítette, hogy a felvételek felhőborítottsága $0 \%$. A müholdképek digitális számokból állnak, azaz az információt kvantált formában tartalmazzák, egy bájtra transzformálva. Ebből a radiancia értékeket elő lehet állítani GRASS 7 segítségével. A müvelet az i.landsat.toar modullal végezhetö el, mely a GRASS Development Team (2016) által kiadott kézikönyv szerint először radiancia értéket számol (1. egyenlet), majd azokat átszámolja reflektancia értékekké (2. egyenlet). A modulnak szüksége van az adott felvétel összes sávjára és a felvétel metaadataira, mely a felvételekkel egy archívumba van csomagolva.

$$
\begin{gathered}
L_{\lambda}=\text { Gain } \times Q C A L+\text { Bias } \\
\text { ahol Gain }=\frac{\text { LMAX }_{\lambda}-\text { LMIN }_{\lambda}}{Q C A L M A X-Q C A L M I N} \\
\text { és Bias }=\text { LMIN }_{\lambda}-\text { Gain } \times Q \text { CALMIN (1) }
\end{gathered}
$$

A NASA (2011) Landsat 7 kézikönyvéből kiolvasható, hogy az LMAX ${ }_{\lambda}$ és az LMIN ${ }_{\lambda}$ értékek sávfüggő kalibrációs konstansok, a QCALMAX 255, azaz a kvantálás felső értéke, a QCALMIN a kvantálás alsó értéke, mely az előfeldolgozást végző szoftvertől függően 0 vagy 1-es értéket vesz fel, a QCAL pedig az adott raszter kvantált értéke (digitális száma). Végül az $\mathrm{L}_{\lambda}$ a radiancia érték W/ $\mathrm{m}^{2} \times \mathrm{sr} \times \mu \mathrm{m}$-ben.

$$
\rho_{p}=\frac{L_{\lambda}}{E S U N_{\lambda} \times \sin \alpha_{s} /\left(\pi \times d^{2}\right)}(2)
$$

A GRASS kézikönyve szerint az ESUNÎt' a Napból érkező sugárzás közepes értéke, az $\alpha_{\mathrm{s}}$ a Nap magassági szöge, míg a d érték a közepes Naptávolság csillagászati egységben kifejezve a felvétel időpontjában. A $\rho_{\mathrm{p}}$ egy mértékegység nélküli planetáris reflektancia érték, mely a visszaverődő sugárzás arányát mutatja meg a beérkező sugárzáshoz képest. Ez a képlet eltér a Landsat 7 kézikönyvben olvashatótól (3. egyenlet), azonban mivel $\theta_{s}$, azaz a Nap zenitszöge komplementere a Nap magassági szögének, könnyedén belátható, hogy $\sin \alpha_{\mathrm{s}}=\cos \theta_{\mathrm{s}}$.

$$
\rho_{p}=\frac{\pi \times L_{\lambda} \times d^{2}}{E S U N_{\lambda} \times \cos \theta_{s}}(3)
$$

Miután a GRASS kiszámolta a reflektancia értékeket, a négy különböző normalizált index kiszámítása következett. Chen et al. (2006) alapján az NDVI (4. egyenlet) és az NDWI (5. egyenlet) mutatók reflektancia értékből számolandóak, míg az NDBI (6. egyenlet) és az NDBaI (7. egyenlet) kvantált értékekből, azaz digitális számokból.

$$
N D V I=\frac{\rho_{\bar{B} 4}-\rho_{\bar{B} 3}}{\rho_{\bar{B} 4}+\rho_{\bar{B} 3}}(4)
$$

A $\rho_{\mathrm{B} 3}$ a hármas sáv, azaz a vörös spektrális tartomány reflektancia értékét jelöli, míg a $\rho_{\mathrm{B} 4}$ a négyes sáv, azaz a közeli infravörös tartomány reflektanciáját. Az NDVI mutató föként a növényzet és a felszíni vizek elkülönítésére alkalmas.

$$
N D W I=\frac{\rho_{B 4}-\rho_{B 5}}{\rho_{B 4}+\rho_{B 5}}(5)
$$

A $\rho_{\mathrm{B} 5}$ a közepes infravörös tartomány, azaz az ötös sáv reflektancia értékeit jelöli. Gao (1996) alapján ez a mérőszám a vegetáció nedvességtartalmával korrelál, így alkalmas lehet a sürü növényzet, a gyér növényzet, és a mocsári növényzet elkülönítésére.

$$
N D B I=\frac{D N_{B 5}-D N_{B 4}}{D N_{B 5}+D N_{B 4}}(6)
$$

$\mathrm{A} \mathrm{DN}_{\mathrm{B} 4}$ és a $\mathrm{DN}_{\mathrm{B} 5}$ a négyes és ötös sávok kvantált értékeit jelölik. Chen et al. (2006) szerint ez az index a beépített területekre érzékeny.

$$
N D B a I=\frac{D N_{B 5}-D N_{B 6}}{D N_{B 5}+D N_{B 6}}(7)
$$

A $\mathrm{DN}_{\mathrm{B} 6}$ a hatos sáv, azaz a termális infravörös tartomány kvantált értékeit jelöli. Zhao et al. (2005) vezette be ezt az indexet a kopár területek automatikus leválogatására, és azok további alosztályokba való besorolására.

Az elkészült indexeken (2. ábra) jól elkülönülnek a legmeghatározóbb felszínborítási típusok, mint a Duna vonala, vagy a Mecsek erdővel borított területe.

Az alaptérképek klaszifikációjának van felügyelt és automatikus módja. A felügyelt módszer során a felhasználó mintaterületeket jelöl ki, melyek az adott területhasználati kategóriát reprezentálják. Ez a lépés is auto- 

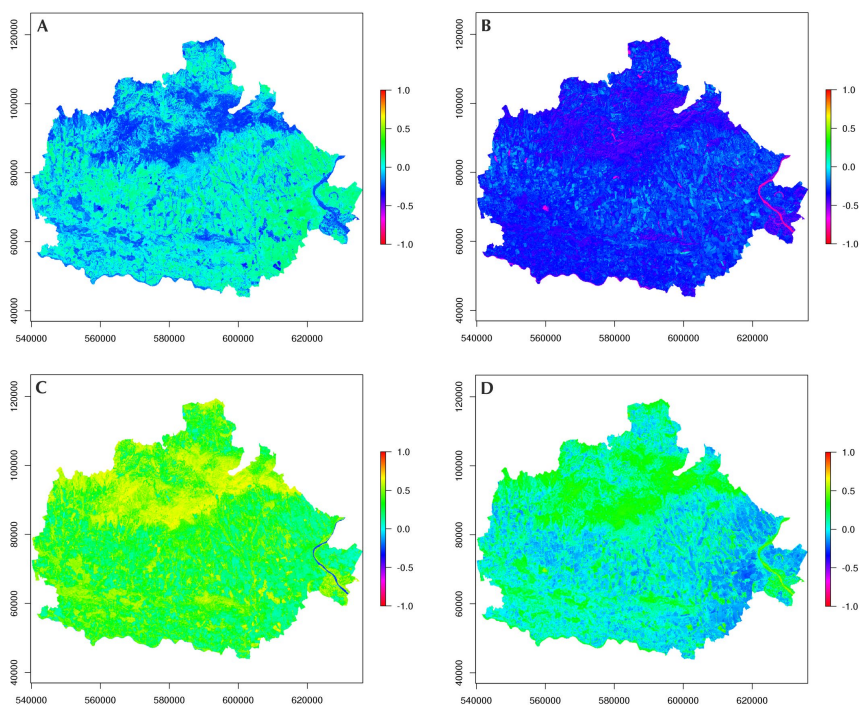

2. ábra. Spektrális indexek $\mathrm{A}$ : NDBI, B: NDBal, C: NDVI, D: NDWI

matizálható klaszteranalízis segítségével. Erre a GRASS i.cluster modulja szolgál, mely a forráskód alapján K-közép módszerrel dolgozik. A K-közép módszer egy iteratív klaszterezési eljárás, mely Ding et al. (2004) szerint a lokális minimum felé konvergál (8. egyenlet). A lokális minimum minden egyes klaszternél a klaszter közepe és a hozzá tartozó pontok közötti távolságnégyzetek összege (négyzetes hiba).

$$
I_{K}=\sum_{k=1}^{K} \sum_{i \in C_{k}}\left(x_{i}-m_{k}\right)^{2}(8)
$$

A felügyelt klasszifikáció első lépéséhez hasonlóan, a klaszterezési eljárás is mintavételezésen alapszik. A kutatáshoz a mintaterületen minden $9 \mathrm{~km}^{2}$-re egy minta jutott, ezért is volt fontos, hogy minden elkülönítendö típushoz elegendő referenciaterület tartozzon. A K-közép módszer kötelező paramétere még az osztályok száma, mely az 1 . táblázatnak megfelelően 6 volt.

A következő lépés az automatikus osztályozásban a mintaterület rasztereinek osztályozása az indexek alapján. A klaszteranalízis végeredménye egy spektrális lenyomat minden csoportra, mely tartalmazza az indexek csoportspecifikus átlagait és kovariancia mátrixait. A spektrális lenyomatok alapján a GRASS i.maxlik modulja képes minden rasztert megfelelő osztályba sorolni. Ez a modul az MLC módszert használja, mely Ahmad et al. (2012) alapján a Bayes statisztika módszereivel vizsgálja minden raszterre azt a valószínüséget, hogy egy bizonyos osztályba tartozik (9. egyenlet). Kiválasztja azt az osztályt, ahová az adott raszter legnagyobb valószínüséggel sorolható, majd besorolja. Opcionális kimenetként készít egy raszteres állományt, melyben az értékek a helyes osztályba sorolás valószínűségét reprezentálják. Ezt a valószínüséget az algoritmus $\chi^{2}$ próbával állapítja meg.

$$
\begin{gathered}
\forall i . P\left(M_{i} \mid \omega\right)>P\left(M_{j} \mid \omega\right) \rightarrow x \in M_{i} \wedge j=i \\
\text { ahol } i \in\{2 \ldots|M|\}, j=1 \\
P\left(M_{i} \mid \omega\right)=\frac{P\left(\omega \mid M_{i}\right) \times P\left(M_{i}\right)}{P(\omega)} \\
\text { ahol } P(\omega)=\sum_{i=1}^{|M|} P\left(\omega \mid M_{i}\right) \times P\left(M_{i}\right)(9)
\end{gathered}
$$

Az M az osztályok halmazát jelöli, az x egy adott rasztert, míg az $\omega$ az adott raszter jellemvektorát a különböző indexeken felvett értékei alapján.

\section{Eredmények}

\subsection{Pontosságvizsgálat}

Az elkészült klasszifikáció az összehasonlíthatóság érdekében újraosztályozásra szorult. Az eredmény (3. ábra) pontossága egy Kappa vizsgálat (Cohen 1960) során számolt százalékos, és $\kappa$ értékekkel jellemezhető (GRASSban r.kappa modul). Congalton (1991) szerint a kiértékelt raszter valódi pontosságát csak közelíteni lehet, a referenciákat tartalmazó minta nagyságától függően alulról, vagy felülröl. Különlegessége az ebben a kutatásban szereplő vizsgálatnak, hogy a valódi pontosságot felülről közelíti meg, így referenciaként az egész vizsgálati területre generált és újraosztályozott CLC50 állományt használja.

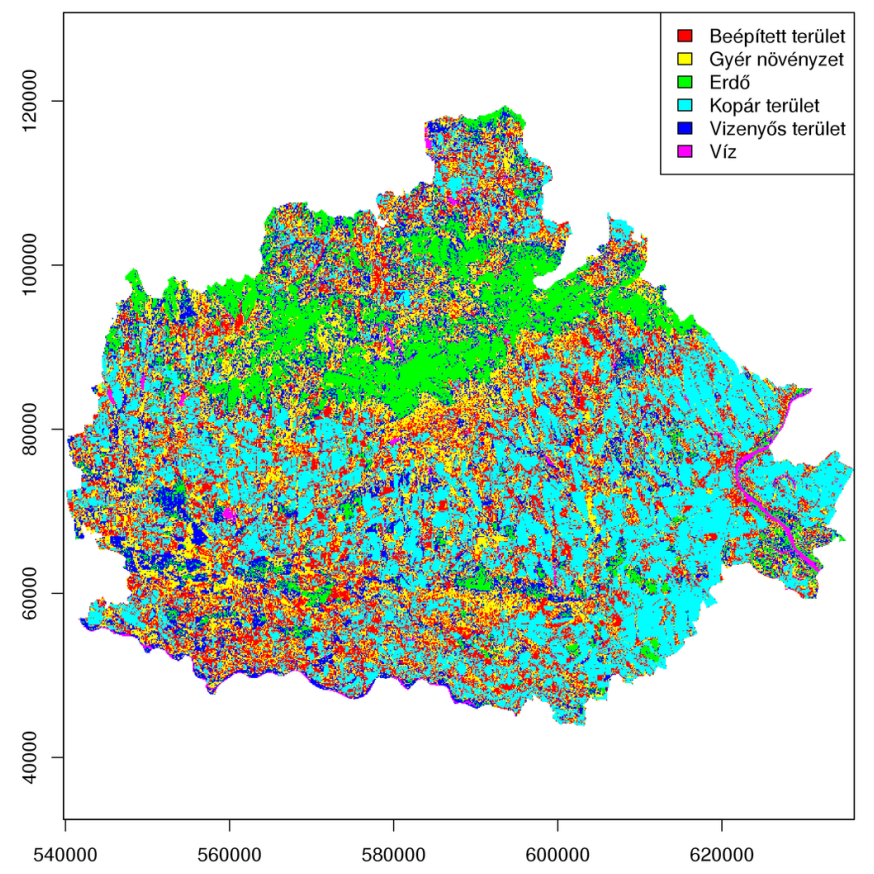

\section{3. ábra. Az automatikus klasszifikáció eredménye}

Bár már a térképen is látszik, hogy az eredmény nem csupán zajos, de a kategóriák többségében pontatlan. Ezt a Kappa Indexel történt pontosságvizsgálat eredménye 
(2. táblázat) is alátámasztja. A teljes területnek csupán $50,62 \%$-át sikerült helyes osztályba sorolni.

\begin{tabular}{cccc}
\hline Osztály & Com. & Om. & к \\
\hline Beépített terület & $91,79 \%$ & $60,95 \%$ & 0,04 \\
Gyér növényzet & $70,06 \%$ & $49 \%$ & 0,21 \\
Erdő & $8,5 \%$ & $55,16 \%$ & 0,88 \\
Kopár terület & $2,82 \%$ & $45,35 \%$ & 0,94 \\
Vizenyős terület & $98,73 \%$ & $80,17 \%$ & 0 \\
Víz & $21,75 \%$ & $39,36 \%$ & 0,78 \\
Összesen & & & $\mathbf{0 , 3 5}$ \\
\hline
\end{tabular}

2. táblázat. A pontosságvizsgálat eredménye.

A Com. oszlop a kategóriák Commission error százalékos értékét tartalmazza, mely a referenciaosztályon kívül eső extra raszterek arányát jelöli. Az Om. oszlop az Omission error szintén százalékos értékét mutatja, mely a referenciaosztályból hiányzó raszterek arányát adja meg (Congalton 1991). Ez a két fajta hiba nagyszerü kiegészítő információkat ad az egyes osztályok hibáinak természetéről. A $\kappa$ érték a teljes pontosságot fejezi ki, mely 0-től 1-ig terjedhet. Landis és Koch (1977) szerint 0,61es értéktől megfelelőnek, míg 0,81-es értéktől majdnem tökéletesnek tekinthető a klasszifikáció.

Bár a kopár területek, az erdők, és a vizek magas $\kappa$ mutatóval rendelkeznek, a hiányzó raszterek aránya igen magas. A jelenség adódhat a CLC50 állomány generalizált természetéből (Büttner et al. (2009) alapján maximum 10\%-ban), azonban jelen esetben inkább valószínúsíthető az indexek alkalmatlanságából adódó pontatlanság, de nem zárható ki a CLC50 hibás újraosztályozásából származó pontatlanság sem.

\subsection{A hiba természetének vizsgálata}

\subsection{1. Újraosztályozásból származó hiba}

Az indexek alkalmatlanságának bizonyítására a tanulmány a meghatározó lépéseket vizsgálta, ezek közül is azokat, melyek egyszerüen meghatározhatóak. Ilyen az újraosztályozásból származó hiba, valamint a hibás klaszterezés. Az újraosztályozásból származó hiba kizárása érdekében érdemes a hibás rasztereket (3. táblázat) jobban szemügyre venni.

A hibás raszterek vizsgálatához a referenciaállomány és a végeredmény közötti különbségből indultam ki. A különbségeket a hiba típusa szerint csoportosítottam, ahol az első szám a helyes csoport azonosítószámát (1. táblázat) mutatja, a második pedig azt az osztályt, amibe a klaszterezés besorolta. Ezeket a csoportokat az eredeti CLC50 állomány alapján alosztályokra bontottam, és megvizsgáltam az alosztályokon belüli hibás raszterek arányát az összes hibás raszterhez (hibaarány), az alcsoportba tartozó összes raszterhez (osztályarány), és a teljes mintaterülethez (teljes arány) képest.

Az eredményből kiolvasható, hogy a legnagyobb hibákat okozó alosztályok osztályaránya az újraosztályozásban nem utal hibára. A klasszifikációban a legnagyobb hibát a 2111-es alosztály okozta, melyek a FÖMI (2009) által kiadott nómenklatúra alapján nagytáblás szántóföldeket jelöl. Az alosztály 35,25\%-át rossz osztályba sorolta, tehát az újraosztályozás megváltoztatása rontana a klasszifikáció pontosságán. A hibát súlyosbítja, hogy a hibás besorolás többsége beépített terület lett, ami két dologra is utal. Egyrészt az indexek alkalmatlanok lehetnek néhány felszínborítási kategória határozott elválasztására a környezetüktől (pl. kisebb szőlők). Másrészt a kiinduló adatok felbontása túl nagy ahhoz, hogy kisebb mesterséges elemeket (pl. utak) pontosan lehatároljon, ugyanakkor nem elég nagy ahhoz, hogy ezek az elemek ne torzítsák el a végeredményt (4. ábra). Az alosztály 10,41\%-a gyér növényzetként került besorolásra, ami olyan területeket is jelölhet, ahol 2000. október 14-én még nem történt meg a betakarítás.

A táblázat azt is megmutatja, hogy vannak olyan alosztályok, melyek átsorolása javíthat az újraosztályozás pontosságán. A 3115-ös alosztály, azaz a lombos erdő ültetvények nagyobb része rossz osztályba került. Itt az átsorolás nem indokolt, mivel a hibát könnyen okozhatja egy fiatal telepítés, ahol a lombkorona nem összefüggö,

\begin{tabular}{|c|c|c|c|c|c|}
\hline Hiba & CLC osztály & $\mathbf{n}$ & Hibaarány & Osztályarány & Teljes arány \\
\hline \multirow{3}{*}{$4-1$} & 2111 & 521962 & $21,48 \%$ & \multirow{3}{*}{$\begin{array}{l}24,84 \% \\
38,32 \%\end{array}$} & $10,61 \%$ \\
\hline & 2112 & 214127 & $8,81 \%$ & & $4,35 \%$ \\
\hline & Egyéb & 5817 & $0,24 \%$ & & $0,12 \%$ \\
\hline \multirow{3}{*}{$3-5$} & 3115 & 198987 & $8,19 \%$ & \multirow{3}{*}{$\begin{array}{l}52,72 \% \\
22,19 \%\end{array}$} & $4,04 \%$ \\
\hline & 3111 & 147120 & $6,05 \%$ & & $2,99 \%$ \\
\hline & Egyéb & 120598 & $4,96 \%$ & & $2,45 \%$ \\
\hline \multirow{3}{*}{$4-2$} & 2111 & 218821 & $9 \%$ & \multirow{3}{*}{$\begin{array}{l}10,41 \% \\
21,29 \%\end{array}$} & $4,45 \%$ \\
\hline & 2112 & 118944 & $4,9 \%$ & & $2,42 \%$ \\
\hline & Egyéb & 7593 & $0,31 \%$ & & $0,15 \%$ \\
\hline \multirow{3}{*}{$3-2$} & 3115 & 81918 & $3,37 \%$ & \multirow{3}{*}{$\begin{array}{c}21,7 \% \\
61,87 \%\end{array}$} & $1,66 \%$ \\
\hline & 3211 & 33217 & $1,37 \%$ & & $0,68 \%$ \\
\hline & Egyéb & 92071 & $3,79 \%$ & & $1,87 \%$ \\
\hline Egyéb & & 901545 & $37,1 \%$ & & $18,32 \%$ \\
\hline Összesen & & 2429839 & $100 \%$ & & $49,38 \%$ \\
\hline
\end{tabular}

3. táblázat. Hibák részletes bontásban. 


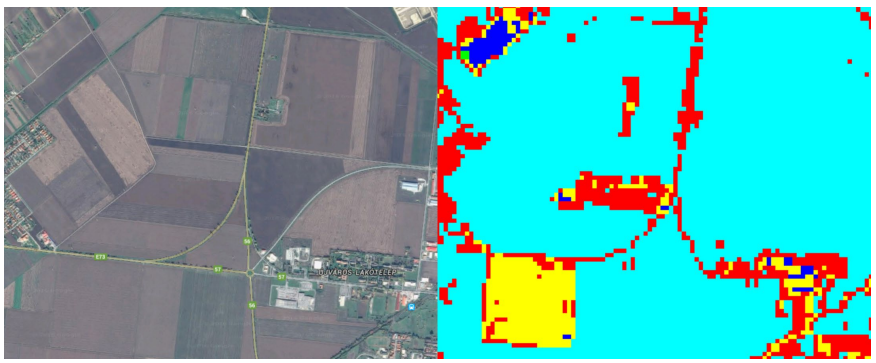

4. ábra. Az 56-os, és 57-es utak hibás klaszterezése Mohács és Lánycsók között. A két sávos (kb. $6 \mathrm{~m}$ széles) utak spektrális torzításának hatására 900 m2-es területek kerültek beépített terület kategóriába. Forrás: Google Maps 2016.

valamint összefüggő aljnövényzet sem alakult ki. Besorolási hibára utal azonban a 3211-es alosztály, ami természetes gyepet jelöl fák és cserjék nélkül. Itt valóban az újraosztályozás tévedett, azonban ennek javítása a végeredményben szignifikáns változást nem hozna.

Összegzésképpen megállapítható, hogy az újraosztályozás nem hibátlan, viszont helytálló. A hibák javítása minimális javulást hozna az automatikus klaszszifikáció pontosságában, a hiba nagy része viszont megmaradna. Így az újraosztályozás, mint fó hibaforrás kizárható.

\subsubsection{Klaszterezésböl származó hiba}

Egy másik könnyen ellenőrizhető, illetve számszerüsíthető hibaforrás a klaszteranalízis, mely a spektrális lenyomatokat hozza létre. A klaszterezés helyességének ellenőrzéséhez szükség van az indexek átlagaira (4. táblázat), valamint kovariancia mátrixaira a referenciaállomány csoportjaira lebontva. Így a klaszteranalízis kivonhatóvá válik a klasszifikációból, és a két eredmény összehasonlítható lesz. Az eredmények közötti különbség mutatja meg a klaszterezés hibáját, de a két eredmény kappa mutatóinak összehasonlításából is lehet következtetni a klaszteranalízis pontosságára.

A kovariancia mátrixok kiszámolására a GRASS-on belül az r.covar modul szolgál. A manuálisan létrehozott spektrális lenyomattal készített klasszifikáció jobbnak bizonyult, mint az automatikus. Itt már a terület $67,56 \%$ át sikerült helyesen besorolni, azonban a részletes kappa elemzés (5. táblázat) érdemi változást nem mutat.

A beépített területek és az erdők osztályozása pontosabb lett, azonban az eddig kiváló pontossággal lehatá-

\begin{tabular}{cccc}
\hline Osztály & Com. & Om. & к \\
\hline Beépített terület & $77,65 \%$ & $47,45 \%$ & 0,19 \\
Gyér növényzet & $69,3 \%$ & $49,38 \%$ & 0,22 \\
Erdő & $16,85 \%$ & $27,38 \%$ & 0,77 \\
Kopár terület & $6,19 \%$ & $29,27 \%$ & 0,86 \\
Vizenyős terület & $95,79 \%$ & $80,41 \%$ & 0,03 \\
Víz & $40,53 \%$ & $36,33 \%$ & 0,59 \\
Összesen & & & $\mathbf{0 , 5 3}$ \\
\hline
\end{tabular}

5. táblázat. A klaszterezés nélküli klasszifikáció kappa elemzésének eredménye.

rolt kopár területek, és jó pontossággal rendelkező vizek veszítettek pontosságukból. A hiba oka csak részlegesen keresendő a klaszterezésben, mivel a K-közép algoritmus sajátosságai is okozhatták. Az algoritmus egymástól jól elválasztható, normál eloszlású csoportokat próbál kialakítani (5. ábra), így a kialakított csoportok szórása, varianciája hasonló, a többi jellemző statisztikai mutatója eltérö, periodikus változást mutat.

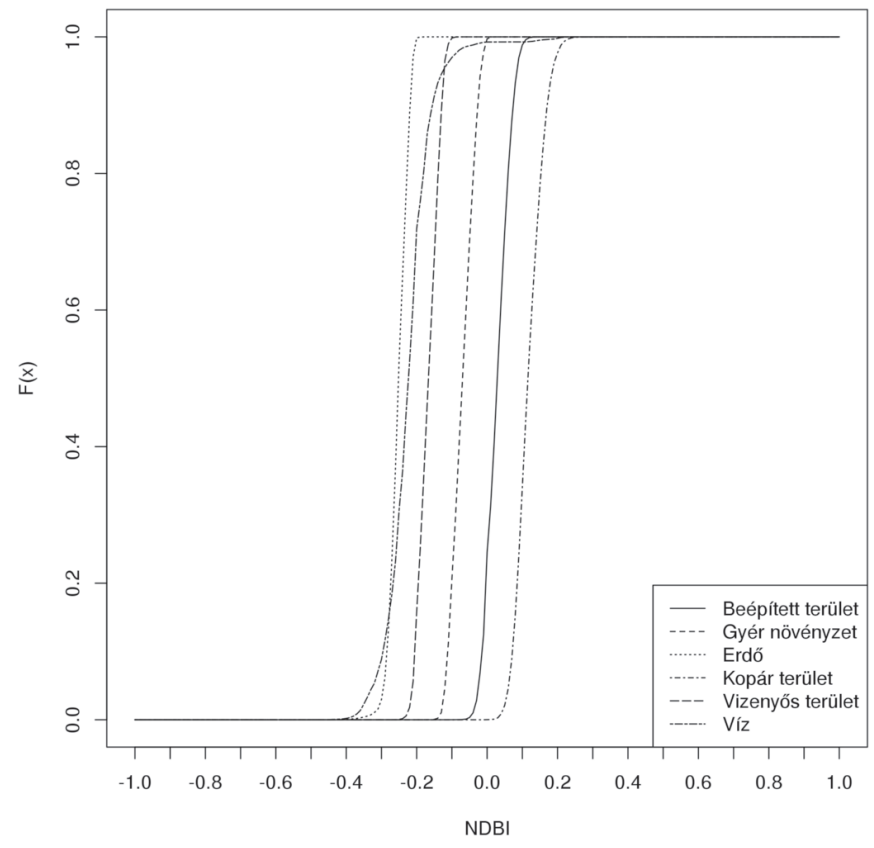

\section{5. ábra. Csoportok eloszlása automatikus klasszifikáció esetén az NDBI indexen.}

Az indexek a referenciacsoportokra kiszámolt statisztikai mutatóiból (4. táblázat) jól látszik azonban, hogy az indexek nem ezeket a tulajdonságokat mutatják. Bár a szórásuk többnyire alacsony, az átlagaik, és a határérté-

\begin{tabular}{|c|c|c|c|c|c|c|c|c|c|c|c|c|c|c|c|c|}
\hline \multirow{2}{*}{ Kat. } & \multicolumn{4}{|c|}{ NDBI } & \multicolumn{4}{|c|}{ NDBaI } & \multicolumn{4}{|c|}{ NDVI } & \multicolumn{4}{|c|}{ NDWI } \\
\hline & $\mathbf{m}$ & $\sigma$ & $1 \%$ & $99 \%$ & m & $\sigma$ & $1 \%$ & $99 \%$ & $\mathbf{m}$ & $\sigma$ & $1 \%$ & $99 \%$ & $\mathbf{m}$ & $\sigma$ & $1 \%$ & $99 \%$ \\
\hline 1 & $-0,04$ & 0,07 & $-0,21$ & 0,12 & $-0,31$ & 0,06 & $-0,48$ & $-0,17$ & 0,35 & 0,1 & 0,12 & 0,56 & 0,1 & 0,08 & $-0,09$ & 0,28 \\
\hline 2 & $-0,07$ & 0,08 & $-0,26$ & 0,12 & $-0,31$ & 0,06 & $-0,47$ & $-0,18$ & 0,44 & 0,09 & 0,18 & 0,64 & 0,13 & 0,09 & $-0,09$ & 0,34 \\
\hline 3 & $-0,18$ & 0,08 & $-0,3$ & 0,07 & $-0,39$ & 0,07 & $-0,55$ & $-0,22$ & 0,53 & 0,08 & 0,25 & 0,66 & 0,25 & 0,09 & $-0,04$ & 0,39 \\
\hline 4 & 0,06 & 0,09 & $-0,22$ & 0,2 & $-0,27$ & 0,07 & $-0,42$ & $-0,2$ & 0,25 & 0,12 & 0,09 & 0,6 & $-0,02$ & 0,1 & $-0,19$ & 0,29 \\
\hline 5 & $-0,06$ & 0,08 & $-0,24$ & 0,12 & $-0,34$ & 0,06 & $-0,56$ & $-0,2$ & 0,42 & 0,09 & 0,17 & 0,6 & 0,12 & 0,09 & $-0,09$ & 0,33 \\
\hline 6 & $-0,16$ & 0,1 & $-0,35$ & 0,11 & $-0,57$ & 0,18 & $-0,8$ & $-0,2$ & 0,14 & 0,24 & $-0,29$ & 0,55 & 0,28 & 0,16 & $-0,08$ & 0,58 \\
\hline
\end{tabular}

4. táblázat. Az indexek néhány releváns statisztikai mutatója a referenciaállomány csoportjaira kiszámolva. 
keik nem különülnek el annyira, hogy a klaszteranalízis megtalálhassa a várt csoportokat. Így a klaszterezés sem hordoz meghatározó mennyiségủ hibát.
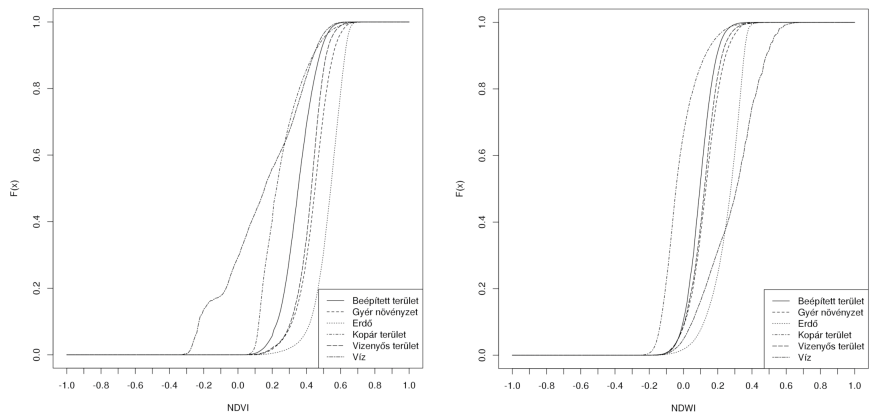

\section{6. ábra. NDVI és NDWI indexek eloszlásfüggvényei a referenciacsoportok területén.}

A hiba forrása így már elég nagy valószínűséggel az indexek alkalmatlansága, azonban érdemes lehet feltárni, pontosan miért alkalmatlanok ezek a normalizált indexek Magyarország területén. A mutatók eloszlása a referenciacsoportok területén (6., 7. ábra) érdekes összefüggésekre világít rá.
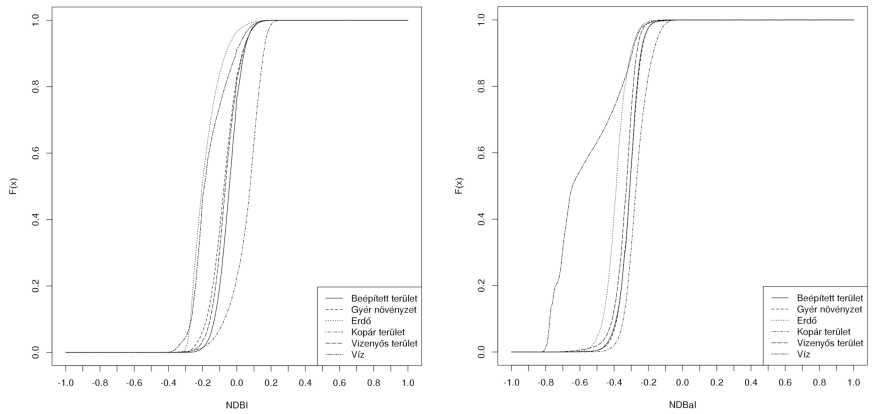

\section{7. ábra. NDBI és NDBal indexek eloszlásfüggvényei a referenciacsoportok területén.}

Az NDVI emeli ki leginkább a célcsoportok spektrális eltéréseit. Az NDWI legfőbb alkalmazási területe a növényzet nedvességtartalmának a kimutatása. Az erdők és a gyér növényzet elkülönítésére maradéktalanul alkalmas, azonban az erdők és a vizek, valamint a gyér növényzet és a vizenyős területek nehezen választhatóak szét ezzel a mutatóval. Váratlan előnye azonban, hogy a kopár területekre is igen érzékeny.

Az NDBaI jól kiemeli a kopár területeket. Azonban Chen et al. (2006) megállapítása, miszerint a 0-nál nagyobb NDBaI értékek a kopár területekkel erősen korrelálnak, Magyarországon megdőlni látszik. Baranya megyében szinte az egész terület 0 alatti értéket vesz fel, és a kopár területek -0,6-os érték alatt szeparálhatóak el. Ennek fő oka lehet a Kína délkeleti részét jellemző vörös- és sárgaföldek eltérö reflektanciája a kontinentális éghajlat jellemző talajaitól közepes, és termális infravörös tartományban.

Az NDBI mutató hozta a leggyengébb eredményt. A mutatónak a beépített területek és a természetes terüle- tek eltérő reflektanciájára kellene érzékenynek lennie, ezzel szemben a kopár területekre érzékeny. Ennek okai egyelőre ismeretlenek, feltárásuk további kutatómunkát igényel. Az okok között szerepelhetnek a kínai és magyar területek közötti beépítettség mennyiségi, és minőségi különbségei, a besugárzás eltérő mértéke, valamint a vidéki városok hőszennyezettségének kisebb mértékéből adódó UHI (Urban Heat Island) jelenség részleges hiánya. Fontos megemlíteni, hogy a vizeket, és az erdőket jól elválasztja a többi csoporttól, ami a többi mutatóval együtt, négy dimenzióban javítja azok elszeparálhatóságát.

\section{4. Összegzés}

A Chen et al. (2006) által alkalmazott indexek vegyesen alkalmazhatóak Magyarországon automatikus klasszifikációra. A K-közép és MLC algoritmusok jó pontossággal határolják le a kopár területeket és a vizeket, valamint közepes pontossággal az erdőket. A többi vizsgálati csoportra azonban nem eléggé érzékenyek. A beépített területek, a gyér növényzet, valamint a vizenyős területek mind a négy indexen összemosódnak, spektrális tulajdonságaik túlságosan hasonlóak. Az NDVI képes leginkább elválasztani a célcsoportokat, viszont pontos lehatárolásra egy mutató, az algoritmusok szemszögéből egy dimenzió nem elegendő. Az NDWI, és az NDBaI nem a várt módon, de hasznosnak bizonyulnak a kopár területek, a vizek, és az erdők elválasztásában. Az NDBI hozta a legrosszabb eredményt, ennek a mutatónak volt a legkevesebb haszna az elemzés során.

Bár a vizsgált indexek automatikus klasszifikációra részlegesen alkalmasak, azaz néhány felszínborítási elemet nagy pontossággal képesek lehatárolni, önállóan nem alkalmazhatóak. Egy teljesen automatizálható és pontos módszer kidolgozásához az itt megírt módszer implementálható, azonban más jellegü, lokalizált, Magyarország viszonyait jól visszaadó mutatókra is szükség van.

\section{Köszönetnyilvánítás}

Szeretnék köszönetet mondani Dr. Szabó Szilárdnak, amiért meglátásaival nem csak tartalmilag, de formailag is sokat sikerült javítani a dolgozaton, valamint Dr. Mucsi Lászlónak, amiért véleményével további perspektívákat adott a kutatásnak. Mindkettejük munkáját nagyra értékelem. 


\section{Irodalomjegyzék}

Ahmad, A. és Quegan, S. (2012). Analysis of maximum likelihood classification on multispectral data. Applied Mathematical Sciences, 6(129), 6425-6436.

Büttner, G., Maucha, G., Bíró, M., és Petrik, O. (2009). Nagyfelbontású nemzeti felszínborítási adatbázis. Földmérési és Távérzékelési Intézet, Környezetvédelmi Távérzékelési Osztály, Budapest. 9 p.

Chen, X.-L., Zhao, H.-M., Li, P.-X., és Yin, Z.-Y. (2006). Remote sensing image-based analysis of the relationship between urban heat island and land use/cover changes. Remote Sensing of Environment, 104, 133-146.

Cohen, J. (1960). A Coefficient of Agreement for Nominal Scales. Educational and Psychological Measurement, 20(1), 37-46.

Congalton, R. G. (1991). A Review of Assessing the Accuracy of Classifications of Remotely Sensed Data. Remote Sensing of Environment, 37, 35-46.

Ding, C. és He, X. (2004). K-means clustering via principal component analysis. Proceedings of the Twenty-first International Conference on Machine Learning, ICML ,04, New York, NY, USA. 29-.

Eredics, A. (2007). Vegetációs Indexméter (NDVI) Tervezése és Fejlesztése. Nyugat-Magyarországi Egyetem Erdőmérnöki Kar Geomatikai, Erdőfeltárási és Vízgazdálkodási Intézet Földmérési és Távérzékelési Tanszék, Sopron. 3-5.

Feranec, J., Hazeu, G., Christensen, S., és Jaffrain, G. (2007). Corine land cover change detection in Europe (case studies of the Netherlands and Slovakia). Land Use Policy, 24, 234-247.

FÖMI (2009). Az 1:50.000 léptékű országos CORINE Felszínborítási (Land Cover) Projekt nómenklatúrája. Földmérési és Távérzékelési Intézet, Környezetvédelmi Távérzékelési Osztály, Budapest. 20 p.
Gao, B.-C. (1996). NDWI - A Normalized Difference Water Index for Remote Sensing of Vegetation Liquid Water From Space. Remote Sensing of Environment, 58, 257-266.

Garrison, T. G., Houston, S. D., Golden, C., Inomata, T., Nelson, Z., és Munson, J. (2008). Evaluating the use of IKONOS satellite imagery in lowland Maya settlement archaelogy. Journal of Archaeological Science, 35, 2770-2777.

GRASS Development Team (2016). Geographic Resources Analysis Support System (GRASS GIS) Software, Version 7.0. Open Source Geospatial Foundation.

Landis, J. R., és Koch, G. G. (1977). The Measurement of Observer Agreement for Categorical Data. Biometrics, 33(1), 159-174.

Lein, J. K. (2003). OhioView: A Case Study in Progress. Journal of Space Communications, 1(3), 29 p.

Mika, J., Utasi, Z., Biró, C., és Kónya, E. P. (2011). Müholdakról távérzékelt adatok feldolgozása és hasznosítása. EKF Matematikai és Informatikai Intézet, Eger. 19-20.

NASA (2011). Landsat 7 Science Data Users Handbook. Landsat Project Science Office at NASA's Goddard Space Flight Center, Greenbelt. 186 p.

USGS (2015). Landsat missions: Imaging the earth since 1972. http://landsat.usgs.gov/about_mission_history. php. Letöltve: 2016. Január 8.

Wulder, M. A.. Masek, J. G., Cohen, W. B., Loveland, T. R., és Woodcock, C. E. (2012). Opening the archive: How free data has enabled the science and monitoring promise of Landsat. Remote Sensing of Environment, $122,2-10$.

Zhao, H. és Chen, X. (2005). Use of normalized difference bareness index in quickly mapping bare areas from TM/ETM+. Geoscience and Remote Sensing Symposium, 2005. IGARSS ,05. Proceedings. 2005 IEEE International, 3, 1666-1668. 
